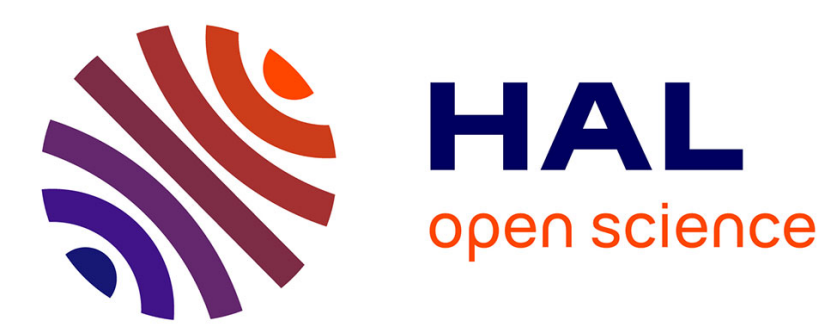

\title{
Enantioselective Stereodivergent Synthesis of Jaspine B and 4-epi-Jaspine B from Axially Chiral Allenols
}

\author{
Heba Alnazer, Tessa Castellan, Yahya Salma, Yves Génisson, Stéphanie
}

Ballereau

\section{- To cite this version:}

Heba Alnazer, Tessa Castellan, Yahya Salma, Yves Génisson, Stéphanie Ballereau. Enantioselective Stereodivergent Synthesis of Jaspine B and 4-epi-Jaspine B from Axially Chiral Allenols. SYNLETT, 2019, 30 (02), pp.185-188. 10.1055/s-0037-1610344 . hal-02059333

\section{HAL Id: hal-02059333 https://hal.science/hal-02059333}

Submitted on 2 Dec 2020

HAL is a multi-disciplinary open access archive for the deposit and dissemination of scientific research documents, whether they are published or not. The documents may come from teaching and research institutions in France or abroad, or from public or private research centers.
L'archive ouverte pluridisciplinaire HAL, est destinée au dépôt et à la diffusion de documents scientifiques de niveau recherche, publiés ou non, émanant des établissements d'enseignement et de recherche français ou étrangers, des laboratoires publics ou privés. 


\title{
Enantioselective stereodivergent synthesis of jaspine B and 4-epi-jaspine $B$ from axially chiral allenols
}

\author{
Alnazer Heba ${ }^{a, b}$ \\ Castellan Tessa ${ }^{a}$ \\ Salma Yahyab \\ Génisson Yves ${ }^{\mathrm{a}}$ \\ Ballereau Stéphanie*a \\ a SPCMIB, UMR5068 CNRS-Université Paul Sabatier-Toulouse \\ III, 118 route de Narbonne, Toulouse, F-31062, France. \\ ${ }^{\mathrm{b}}$ Laboratory of Applied Chemistry (LAC), Faculty of Science III, \\ Lebanese University, P.O. Box 826, Tripoli, Lebanon \\ ballereau@chimie.ups-tlse.fr
}

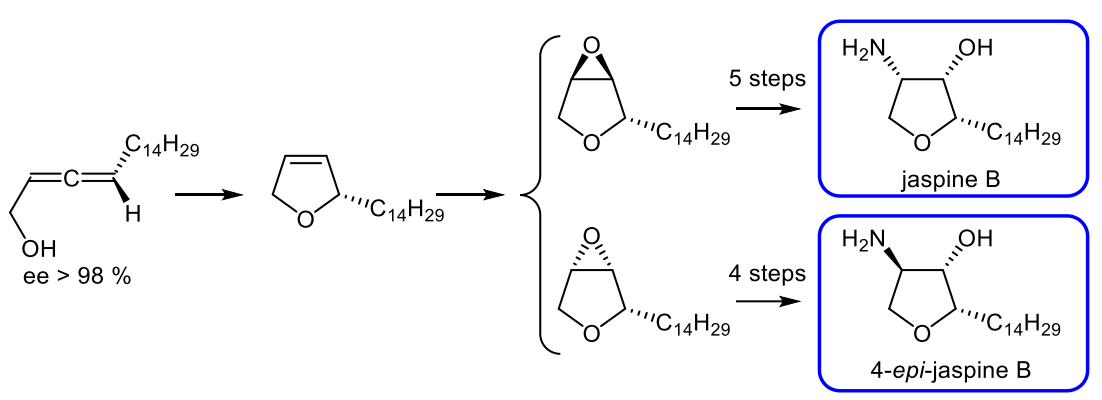

Abstract A short enantioselective synthetic route to the cytotoxic marine natural jaspine B has been developed. A chiral nonracemic primary $\alpha$-allenol, obtained from pentadecanal, gave access to an enantioenriched 2-tetradecyl-2,5-dihydrofuran as key intermediate. A stereodivergent functionalization of this dihydrofuran allowed access in few steps to jaspine B and its 4-epimer.

Key words jaspine B, pachastrissamine, allenol, enatioselective allenylation, epoxydation

Jaspine B, also known as pachastrissamine (1, Fig 1), is a natural anhydrophytosphingosine isolated independently from two different marine sponges, Jaspis sp. ${ }^{1}$ and Pachastrissa sp., ${ }^{2}$ respectively. This marine lipid proved to be cytotoxic at a sub-micromolar concentration on several cancer cell lines. ${ }^{1-3}$ Jaspine $B$ and its stereoisomers were also described as moderate to potent in vitro inhibitors of sphingosine kinases (SphKs). ${ }^{4}$ Among all eight stereoisomers of jaspine B, the (2S,3S,4R)-isomer (4-epi-jaspine B (2), Fig 1) was identified as the most potent inhibitor of SphKs 1 and 2.

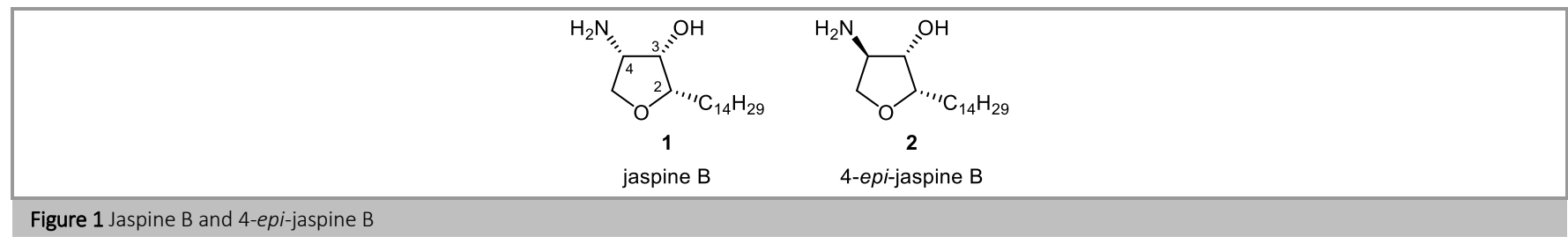

Because of these very interesting biological activities combined with a simple and unique structure, many syntheses of jaspine B and its stereoisomers have been reported. ${ }^{5}$ Nevertheless among the twenty total syntheses described for jaspine B, only less than half are enantioselective synthesis starting from achiral substrates. ${ }^{6}$ Regarding the 4 -epi-jaspine $\mathrm{B}$, all the reported syntheses rely on the "Chiron" approach. ${ }^{3 \mathrm{~h}, 4,7}$ It can be noted however that an enantioselective synthesis of the enantiomer of 4-epi-jaspine B (that is 2,3-epijaspine B) has been reported in the literature. ${ }^{\mathrm{h}}$

We report herein an enantioselective route to jaspine B (1) and its 4-epimer 2. According to the designed retrosynthetic pathway (Scheme 1), 1 and $\mathbf{2}$ could be achieved by the stereodivergent functionalization of the double bond of the enantioenriched 2-tetradecyl2,5-dihydrofuran (3). This dihydrofuran could result from the cycloisomerization of the chiral non-racemic primary $\alpha$-allenol 4 obtained by the enantiocontrolled allenylation of propargylic alcohol with pentadecanal. 


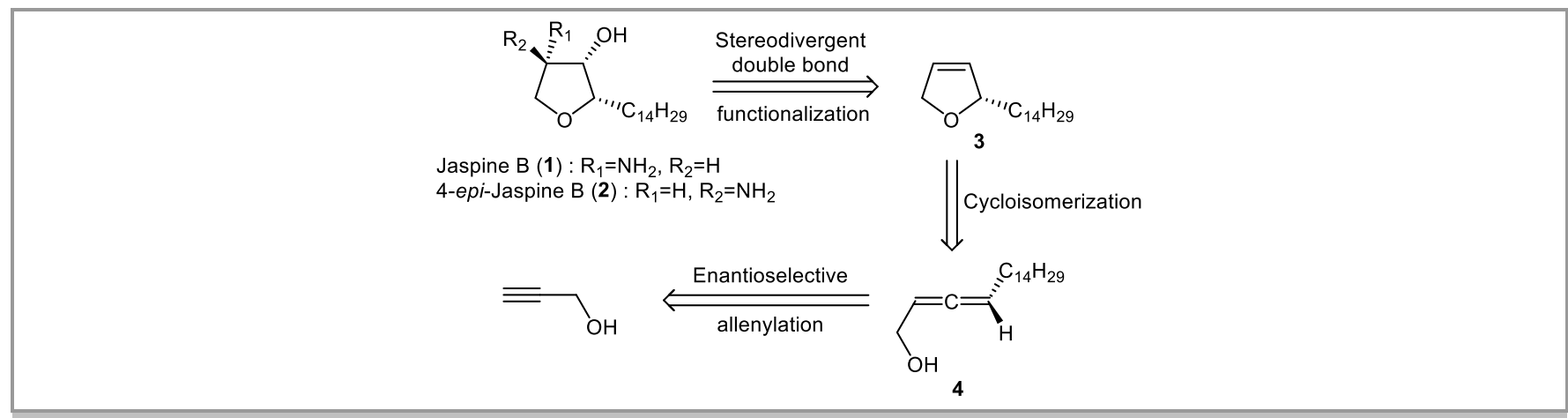

Scheme 1 Retrosynthetic approach to jaspine B and 4-epi-jaspine B

Allenes, more precisely alkoxyallenes, have already been used by Reissig and coll. to build up the functionalized tetrahydrofuran core of jaspine B. ${ }^{8}$ However, this approach doesn't involve an enantioselective access to allenes but requires the use of a carbohydrate-derived chiral auxilliary. Ohno and coll. reported the use of a chiral bromoallene, derived from $(S)$-Garner's aldehyde, to access jaspine B. ${ }^{9}$

Since functionalized axially chiral allenes have been largely used for the synthesis of natural products, ${ }^{10}$ we planned to use chiral nonracemic allenol to access jaspine B. In the present asymmetric synthetic route, the key intermediate is the enantioenriched primary $\alpha$ allenol 4, its enantiopurity being determining for the rest of synthesis. Allenol $\mathbf{4}$ was obtained in one step by the highly enantioselective allenylation of propargylic alcohol developed by Ma and coll.. ${ }^{11}$ Reaction of pentadecanal with propargylic alcohol in the presence of $(R)$ $\alpha, \alpha$-diphenylprolinol and $\mathrm{CuBr}_{2}$ delivered $\mathbf{4}^{12}$ in $67 \%$ yield and $98 \%$ enantiomeric excess (Scheme 2). The $S_{a}$ absolute configuration of the chiral allenol 4, induced by the use of $(R)$ - $\alpha, \alpha$-diphenylprolinol, is in agreement with its dextrogyre character, all $R a$ isomers analogues with shorter alkyl chains described by Ma and coll. having negative optical rotation values. ${ }^{11 a}$

In the next step of the synthesis, 2-tetradecyl-2,5-dihydrofuran (3) was obtained through treatment with a catalytic amount of $\mathrm{AgNO}_{3}$ in $81 \%$ yield. At that stage, the $S$ configuration at C-2 and the enantiomeric purity of $\mathbf{3}$ were based on those of allenol $\mathbf{4}$. Silver-catalyzed cyclisation of enantioenriched $\alpha$-allenols is indeed known to occur through a stereospecific axial to centered chirality transfer. ${ }^{13}$ This assignment could later be confirmed by comparison of the optical rotation value of the final products with values reported in the literature.

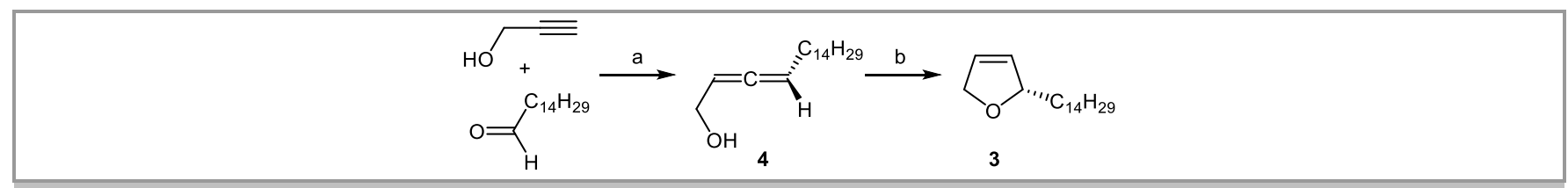

Scheme 2 Reagents and conditions: a) $\mathrm{CuBr}_{2}(20 \%),(R)$ - $\alpha, \alpha$-diphenylprolinol, dioxane, $130^{\circ} \mathrm{C}, 12 \mathrm{~h}, 67 \%, 98 \%$ ee; b) $\mathrm{AgNO}_{3}(10 \%)$, acetone $/ \mathrm{H}_{2} \mathrm{O}, 50^{\circ} \mathrm{C}, 18 \mathrm{~h}, 81 \%$.

The C14 alkyl chain being installed at C-2 with the $S$ absolute configuration corresponding to the naturally occurring compound, the next step en route to jaspine B was the functionalization of the dihydrofuran olefin to introduce the vicinal cis amino-alcohol moiety.

Despite intense efforts, our attempts to generate this cis amino-alcohol in a single step from dihydrofuran $\mathbf{3}$ remained unfruitful. Among the several cis selective aminohydroxylation methods we tried, the protocol employing benzoyloxycarbamate developed by Luxenburger and coll. ${ }^{14}$ allowed us to isolate with a low yield the amino-alcohol $\mathbf{5}$ (Scheme 3) as a major product of a complex reaction mixture. This issue is likely due to the poor regio- or/and diastereoselectivity of this transformation. In addition to this low yield, thorough analysis of NMR spectra revealed that the major product $\mathbf{5}$ was the unwanted regio- and stereoisomer unfitted for the synthesis of jaspine B.

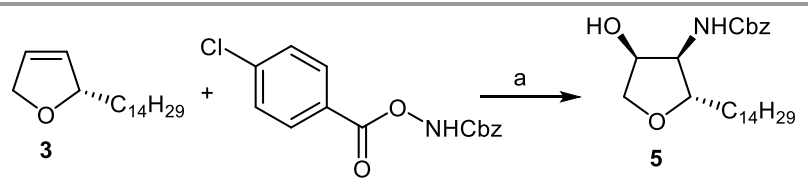

Scheme 3 Reagents and conditions: a) $\mathrm{OsO} 4$ (5\%), $\mathrm{CH}_{3} \mathrm{CN}-\mathrm{H}_{2} \mathrm{O}(8: 1), \mathrm{rt}, 24 \mathrm{~h}, 20 \%$.

We then considered alternative strategies to functionalize the double bond of dihydrofuran 3 and reach the targeted jaspine B and its 4epi enantiomer. A two-step procedure based on the epoxidation followed by a regioselective ring opening was selected. ${ }^{15}$ We examined several epoxidizing reagents and found that trifluoroperacetic acid gave significantly better results than others. Trifluoroperacetic acid, prepared in situ by reaction between urea-hydrogen peroxide and trifluoroacetic anhydride, ${ }^{16}$ reacted with dihydrofuran 3 to give the two epoxides trans-6 and cis-6, isolated in 44\% and 35\% yield respectively (Scheme 4). ${ }^{17}$ Each of the stereoisomeric epoxides 6, easily separated by chromatography on alumina, represented a high added-value intermediate for the selective preparation of one of the two targeted jaspine B stereoisomers. 


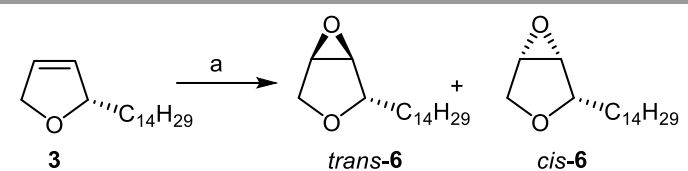

Scheme 4 Reagents and conditions: a) urea- $\mathrm{H}_{2} \mathrm{O}_{2}$ complex, TFAA, $\mathrm{CH}_{2} \mathrm{Cl}_{2}, \mathrm{rt}, 15 \mathrm{~min}$, trans- $644 \%$ and cis-6 $35 \%$.

Epoxides 6 were thus engaged separately in a ring opening reaction. The oxirane ring of trans- 6 was opened using sodium azide in DMF at $120^{\circ} \mathrm{C}$ for 4 days to give 1,2-azido alcohol 7 as the only regioisomer (Scheme 5). Other reaction conditions tested $\left(\mathrm{NaN}_{3} / \mathrm{NH}_{4} \mathrm{Cl}\right.$ or $\mathrm{TMSN}_{3} / \mathrm{BF}_{3} \cdot \mathrm{Et}_{2} \mathrm{O}$ ), despite of giving sometimes faster transformations, did not revealed so regioselective. Note that azido alcohol 7 is a direct precursor of 3-epi jaspine B by hydrogenolysis. In order to obtain $(2 S, 3 S, 4 S)$ absolute configuration of jaspine $\mathrm{B}$, the configuration at C-3 of $\mathbf{7}$ has first to be inverted by means of an oxidation/reduction sequence for instance. Treatment of alcohol $\mathbf{7}$ with Dess-Martin periodinane thus smoothly delivered ketone $\mathbf{8}$ that was engaged in the next step without purification. The diastereoselectivity of the reduction of the carbonyl of $\mathbf{8}$ was influenced by the nature of the reducing agent as well as the reaction temperature. A complete diastereoselectivity could be achieved using sodium borohydride in the presence of cerium chloride at $-78^{\circ} \mathrm{C}$. Azido alcohol 9 was obtained in a $72 \%$ yield over the two steps. As described in the literature, ${ }^{6 \mathrm{~d}, 18}$ catalytic hydrogenation of $\mathbf{9}$ gave access to jaspine B (1) ${ }^{19}$ with a $87 \%$ yield. The enantioselective synthesis of jaspine B was thus achieved in seven steps and $12 \%$ overall yield from pentadecanal.

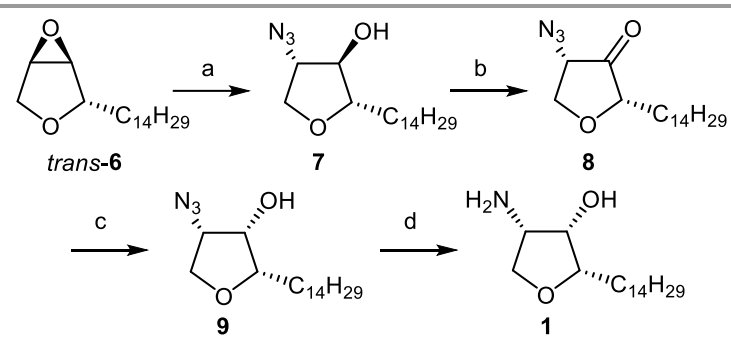

Scheme 5 Reagents and conditions: a) $\mathrm{NaN}_{3}, \mathrm{DMF}, 120^{\circ} \mathrm{C}, 4$ days, $81 \%$; b) Dess-Martin periodinane, $\mathrm{CH}_{2} \mathrm{Cl}_{2}, 0^{\circ} \mathrm{C}$ to rt, $\left.5 \mathrm{~h} ; \mathrm{c}\right) \mathrm{NaBH} \mathrm{Cl}_{4}, \mathrm{CeCl}_{3}, \mathrm{MeOH}-78^{\circ} \mathrm{C}, 8 \mathrm{~h}, 72 \%$ from 7; d) $\mathrm{H}_{2}, \mathrm{Pd} / \mathrm{C}, \mathrm{MeOH}-\mathrm{CH}_{2} \mathrm{Cl}_{2}, \mathrm{rt}, 1 \mathrm{~h}, 87 \%$.

Similarly, epoxide cis-6 was engaged in an oxirane opening reaction with an azide. There again the best regioselectivity was obtained with sodium azide in DMF at $120^{\circ} \mathrm{C}$ even if in this case a mixture of regioisomers $\mathbf{1 0}$ and $\mathbf{1 1}$ was obtained (Scheme 6). This regioselectivity, lower than that of epoxide trans- $\mathbf{6}$ ring opening, can be explain by the weaker steric hindrance engendered by the cis alkyl chain, now in the opposite direction of the azide incoming trajectory, allowing the attack at $\mathrm{C}-3$ to occur as a competitive process.

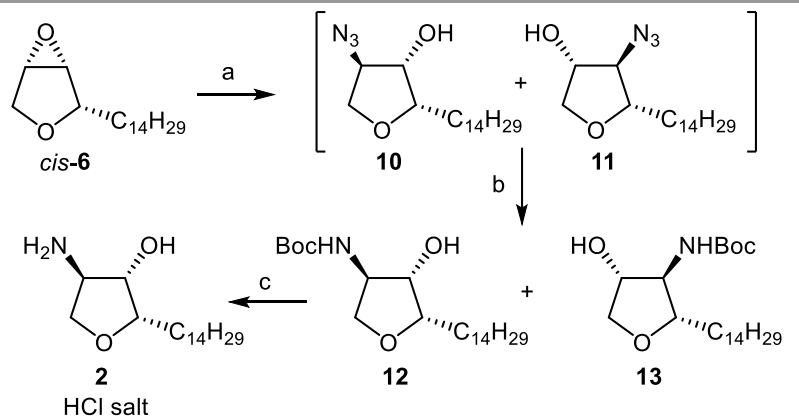

Scheme 6 Reagents and conditions: a) $\mathrm{NaN}_{3}, \mathrm{DMF}, 120^{\circ} \mathrm{C}$, 4 days; b) $\mathrm{H}_{2}, \mathrm{Pd} / \mathrm{C}, \mathrm{Boc}_{2} \mathrm{O}, \mathrm{EtOAc}-\mathrm{CH}_{2} \mathrm{Cl}_{2}, \mathrm{rt}, 1 \mathrm{~h}, 1267 \%, 13 \mathrm{17 \%}$; c) $\mathrm{HCl}, \mathrm{MeOH}, 0^{\circ} \mathrm{C}$ to rt, $24 \mathrm{~h}, 99 \%$.

The mixture of azido alcohols $\mathbf{1 0}$ and $\mathbf{1 1}$ could not be separated and was engaged in a hydrogenolysis reaction in the presence of di-tertbutyl dicarbonate allowing the one-pot reduction of azido group and tert-butoxycarbonyl protection of the formed amine. The two amino alcohols 12 and 13 were then separated easily by column chromatography and obtained in $67 \%$ and $17 \%$ yield respectively. Next, the tert-butyl carbamate of the major regioisomer 12 was cleaved off with methanolic $\mathrm{HCl}^{20}$ to give the expected 4-epi-jaspine $\mathrm{B}(2)$ in $99 \%$ yield as its hydrochloride salt. ${ }^{21}$ The enantioselective synthesis of 4-epi-jaspine B could thus be achieved in six steps and $12 \%$ overall yield from pentadecanal.

In conclusion, we have developed an enantioselective stereodivergent synthesis of jaspine B and 4-epi-jaspine B. The enantioselectivity of the described synthesis relies on the enantiocontrolled allenylation of propargylic alcohol with pentadecanal giving the key axially chiral allenol 4. Stereodiversity is introduced by means of the epoxidation of 2-tetradecyl-2,5-dihydrofuran 3 giving access to diastereoisomeric oxiranes trans-6 and cis-6, precursors of jaspine B and 4-epi-jaspine B respectively. This synthetic route is one of the most straightforward enantioselective accesses to jaspine B and represents the first enantioselective synthesis of 4-epi-jaspine B.

\section{Funding Information}


This work was supported by grants $(\mathrm{AH})$ from research projects at the Lebanese University.

\section{Acknowledgment}

We are thankful to Isabelle Fabing for technical assistance on UPC ${ }^{2}$ provided by the Integrated Screening Platform of Toulouse (PICT, IBiSA). The management committee of scientific research at the Lebanese University is gratefully acknowledged.

\section{References and Notes}

Ledroit, V.; Debitus, C.; Lavaud, C.; Massiot, G. Tetrahedron Lett. 2003, 44, 225.

(2) Kuroda, I.; Musman, M.; Ohtani, I. I.; Ichiba, T.; Tanaka, J.; Gravalos, D. G.; Higa, T. J. Nat. Prod. 2002, 65, 1505.

(3) (a) Liu, J.; Du, Y. G.; Dong, X. M.; Meng, S. C.; Xiao, J. J.; Cheng, L. J. Carbohydr. Res. 2006, 341, 2653. (b) Canals, D.; Mormeneo, D.; Fabrias, G.; Llebaria, A.; Casas, J.; Delgado, A. Bioorg. Med. Chem. 2009, 17, 235. (c) Salma, Y.; Lafont, E.; Therville, N.; Carpentier, S.; Bonnafe, M. J.; Levade, T.; Génisson, Y.; Andrieu-Abadie, N. Biochem. Pharmacol. 2009, 78, 477. (d) Rives, A.; Ladeira, S.; Levade, T.; Andrieu-Abadie, N.; Génisson, Y. J. Org. Chem. 2010, 75, 7920. (e) Ghosal, P.; Ajay, S.; Meena, S.; Sinha, S.; Shaw, A. K. Tetrahedron: Asymmetry 2013, 24, 903. (f) Santos, C.; Fabing, I.; Saffon, N.; Ballereau, S.; Génisson, Y. Tetrahedron 2013, 69, 7227. (g) Kwon, Y.; Song, J.; Bae, H.; Kim, W.-J.; Lee, J.-Y.; Han, G.-H.; Lee, S. K.; Kim, S. Marine Drugs 2015, 13, 824. (h) Martinková, M.; Mezeiová, E.; Fabiš́́ková, M.; Gonda, J.; Pilátová, M.; Mojžišš J. Carbohydr. Res. 2015, $402,6$.

(4) Yoshimitsu, Y.; Oishi, S.; Miyagaki, J.; Inuki, S.; Ohno, H.; Fujii, N. Bioorg. Med. Chem. 2011, 19, 5402.

(5) (a) Abraham, E.; Davies, S. G.; Roberts, P. M.; Russell, A. J.; Thomson, J. E. Tetrahedron: Asymmetry 2008, 19, 1027. (b) Ballereau, S.; Baltas, M.; Génisson, Y. Curr. Org. Chem. 2011, 15, 953. (c) Martinková, M.; Gonda, J. Carbohydr. Res. 2016, 423, 1. (d) Pashikanti, S.; Ukani, R.; David, S. A.; Datta, A. Synthesis 2017, 49, 2088.

(6) (a) Abraham, E.; Candela-Lena, J. I.; Davies, S. G.; Georgiou, M.; Nicholson, R. L.; Roberts, P. M.; Russell, A. J.; Sanchez-Fernandez, E. M.; Smith, A. D.; Thomson, J. E. Tetrahedron: Asymmetry 2007, 18, 2510. (b) Yakura, T.; Sato, S.; Yoshimoto, Y. Chem. Pharm. Bull. 2007, 55, 1284. (c) Abraham, E.; Brock, E. A.; Candela-Lena, J. I.; Davies, S. G.; Georgiou, M.; Nicholson, R. L.; Perkins, J. H.; Roberts, P. M.; Russell, A. J.; SanchezFernandez, E. M.; Scott, P. M.; Smith, A. D.; Thomson, J. E. Org. Biomol. Chem. 2008, 6, 1665. (d) Enders, D.; Terteryan, V.; Palecek, J. Synthesis 2008, 2278. (e) Venkatesan, K.; Srinivasan, K. V. Tetrahedron: Asymmetry 2008, 19, 209. (f) Salma, Y.; Ballereau, S.; Maaliki, C.; Ladeira, S.; AndrieuAbadie, N.; Génisson, Y. Org. Biomol. Chem. 2010, 8, 3227. (g) Urano, H.; Enomoto, M.; Kuwahara, S. Biosci. Biotechnol. Biochem. 2010, 74, 152. (h) Llaveria, J.; Díaz, Y.; Matheu, M. I.; Castillón, S. Eur. J. Org. Chem. 2011, 1514. (i) Dhand, V.; Chang, S.; Britton, R. J. Org. Chem. 2013, $78,8208$.

(7) (a) Cresswell, A. J.; Davies, S. G.; Lee, J. A.; Morris, M. J.; Roberts, P. M.; Thomson, J. E. J. Org. Chem. 2012, 77, 7262. (b) Yoshimitsu, Y.; Miyagaki, J.; Oishi, S.; Fujii, N.; Ohno, H. Tetrahedron 2013, 69, 4211.

(8) Schmiedel, V. M.; Stefani, S.; Reissig, H.-U. Beilstein J. Org. Chem. 2013, 9, 2564.

(9) (a) Inuki, S.; Yoshimitsu, Y.; Oishi, S.; Fujii, N.; Ohno, H. Org. Lett. 2009, 11, 4478. (b) Inuki, S.; Yoshimitsu, Y.; Oishi, S.; Fujii, N.; Ohno, H. J. Org. Chem. 2010, 75, 3831.

(10) (a) Yu, S.; Ma, S. Angew. Chem. Int. Ed. 2012, 51, 3074. (b) Muñoz, M. P. Chem. Soc. Rev. 2014, 43, 3164. (c) Zhou, J.; Fu, C.; Ma, S. Nature Commun. 2018, 9, 1654 .

(11) (a) Huang, X.; Cao, T.; Han, Y.; Jiang, X.; Lin, W.; Zhang, J.; Ma, S. Chem. Commun. 2015, 51, 6956. (b) Tang, X.; Huang, X.; Cao, T.; Han, Y.; Jiang, X.; Lin, W.; Tang, Y.; Zhang, J.; Yu, Q.; Fu, C.; Ma, S. Org. Chem. Front. 2015, 2, 688.

(12) $\quad\left(\boldsymbol{S}_{\boldsymbol{a}}\right)$-octadeca-2,3-dien-1-ol (4): To a flame-dried Schlenk tube with a teflon plug were added sequentially $\mathrm{CuBr}_{2}(132 \mathrm{mg}$ $0.59 \mathrm{mmol}$ ), $(R)$ - $\alpha, \alpha$-diphenylprolinol $(750 \mathrm{mg}, 2.96 \mathrm{mmol}$ ), propargylic alcohol (255 $\mu \mathrm{L}, 248 \mathrm{mg}, 4.42 \mathrm{mmol})$, pentadecanal (1.0 g, 4.42 $\mathrm{mmol}$ ) and dioxane $(14 \mathrm{~mL})$ under nitrogen atmosphere. The Schlenk tube was then sealed and the reaction mixture was placed in a preheated oil bath at $130^{\circ} \mathrm{C}$ for $12 \mathrm{~h}$. After cooling to $\mathrm{rt}$, the resulting brown mixture was then diluted with ether ( $30 \mathrm{~mL}$ ) and washed with an aqueous solution of hydrochloric acid $(3 \mathrm{M}, 20 \mathrm{~mL})$. The organic layer was separated and the aqueous layer then extracted with ether $(20 \mathrm{~mL})$. The organic phases were collected, washed with saturated $\mathrm{NaCl}$ solution, dried over magnesium sulfate and concentrated to dryness to give a residue which was purified by flash chromatography on silica gel (EtOAc/petroleum ether 1:8) to give the allenol 4 (530 mg, 67\% yield). ${ }^{1} \mathrm{H}-\mathrm{NMR}\left(\mathrm{CDCl}_{3}, 300 \mathrm{MHz}\right) \delta(\mathrm{ppm}): 5.4-5.2(\mathrm{~m}, 2 \mathrm{H}, \mathrm{H} 2$ and $\mathrm{H} 4) ; 4.11$ (dd, $\left.J=5.4,3.3,2 \mathrm{H}, \mathrm{H} 1\right) ; 2.02$ (ddt, $J=9.9,6.9$, $3.6 \mathrm{~Hz}, 2 \mathrm{H}, \mathrm{H} 5$ ); 1.53 (bs, 1H, OH); 1.45-1.2 (m, 24H, H6-H17); 0.95-0.8 (m, 3H, H18). ${ }^{13 \mathrm{C}-\mathrm{NMR}}$ (CDCl, $\left.75 \mathrm{MHz}\right) \delta$ (ppm): 203.1 (C3); 94.3 (C4); 91.9 (C2); 60.9 (C1); 32.0 (C5); 29.8 29.6, 29.5, 29.3, 29.2, 28.8, 22.8 (C6-C17); 14.3 (C18). HRMS m/z: calcd for $\mathrm{C}_{18} \mathrm{H}_{35} \mathrm{O}$ [M+H]+: 267.2688; found: 267.2688 . $[\alpha]_{\mathrm{D}}{ }^{25}=+44.3\left(\mathrm{c} 0.51, \mathrm{CHCl}_{3}\right.$ ). $98 \%$ ee (SFC conditions: Chiralcel IA-3 column, $\mathrm{CO}_{2}$ to $\mathrm{CO}_{2}-\mathrm{MeOH}^{2}$ 95:5, 2.0 $\mathrm{mL} / \mathrm{min}, \lambda=210 \mathrm{~nm}, t_{\mathrm{R}}($ minor $)=6.6 \mathrm{~min}, t_{\mathrm{R}}($ major $\left.)=6.9 \mathrm{~min}\right)$.

(13) (a) Ye, J.; Fan, W.; Ma, S. Chem. Eur. J. 2013, 19, 716. (b) Marshall, J. A.; Wang, X. J. J. Org. Chem. 1991, 56, 4913.

(14) Harris, L.; Mee, S. P. H.; Furneaux, R. H.; Gainsford, G. J.; Luxenburger, A. J. Org. Chem. 2011, 76, 358.

(15) Zhao, M.-L.; Zhang, E.; Gao, J.; Zhang, Z.; Zhao, Y.-T.; Qu, W.; Liu, H.-M. Carbohydr. Res. 2012, 351, 126.

(16) Trost, B. M.; Brown, B. S.; McEachern, E. J.; Kuhn, O. Chem. Eur. J. 2003, 9, 4442.

(17) $\quad(1 S, 2 S, 5 R)$-2-tetradecyl-3,6-dioxabicyclo[3.1.0]hexane $\quad($ trans-6) and $\quad(1 R, 2 S, 5 S)$-2-tetradecyl-3,6dioxabicyclo[3.1.0]hexane (cis-6): Trifluoroacetic acid $(1.29 \mathrm{~mL}, 9 \mathrm{mmol})$ was added slowly to a solution of $(S)-2$-tetradecyl-2,5dihydrofuran ( $400 \mathrm{mg}, 1.50 \mathrm{mmol}$ ) and urea-hydrogen peroxide complex $(2.8 \mathrm{~g}, 22.5 \mathrm{mmol})$ in $\mathrm{CH}_{2} \mathrm{Cl}_{2}(20 \mathrm{~mL})$. After $15 \mathrm{~min}$ stirring at rt, the reaction mixture was diluted with an aqueous solution of $\mathrm{Na}_{2} \mathrm{SO}_{3}(1 \mathrm{M}, 15 \mathrm{~mL})$ and extracted with $\mathrm{CH}_{2} \mathrm{Cl}_{2}(3 \times 20 \mathrm{~mL})$. The organic phases were collected, dried over magnesium sulfate and concentrated to dryness to give a residue which was purified by flash chromatography on neutral alumina (EtOAc/petroleum ether 2:98) to give the epoxide trans-6 (188 mg, 44\%) and epoxide cis-6 (149 mg, 35\%) 
trans-6: ${ }^{1} \mathrm{H}-\mathrm{NMR}\left(\mathrm{CDCl}_{3}, 300 \mathrm{MHz}\right) \delta(\mathrm{ppm}): 4.1-4.0(\mathrm{~m}, 1 \mathrm{H}, \mathrm{H} 2) ; 3.97(\mathrm{~d}, \mathrm{~J}=10.6,1 \mathrm{H}, \mathrm{H} 5 \mathrm{a}) ; 3.75(\mathrm{dd}, \mathrm{J}=3.0,0.7,1 \mathrm{H}, \mathrm{H} 4) ; 3.70(\mathrm{~d}, \mathrm{~J}=$ 10.6, 1H, H5b); 3.58 (d, J = 3.0, 1H, H3); 1.5-1.35 (m, 2H, H1'); 1.35-1.2 (m, 24H, H2'-H13'); 0.95-0.8 (m, 3H, H14'). ${ }^{13} \mathrm{C}_{-}-\mathrm{NMR}^{\prime}\left(\mathrm{CDCl}_{3}, 75\right.$ MHz) $\delta$ (ppm): 77.8 (C2); 66.1 (C5); 59.1 (C3); 56.0 (C4); 32.1, 31.1, 29.8, 29.7, 29.6, 29.5, 25.6, 22.8 (C1'-C13'); 14.3 (C14'). HRMS m/z: calcd for $\mathrm{C}_{18} \mathrm{H}_{35} \mathrm{O}_{2}[\mathrm{M}+\mathrm{H}]^{+}: 283.2637$; found: $283.2645 .[\alpha]_{\mathrm{D}^{25}}=-11.8\left(\mathrm{c} 1.23, \mathrm{CHCl}_{3}\right)$.

cis-6: ${ }^{1} \mathrm{H}-\mathrm{NMR}\left(\mathrm{CDCl}_{3}, 300 \mathrm{MHz}\right) \delta(\mathrm{ppm}): 4.04(\mathrm{~d}, \mathrm{~J}=10.6,1 \mathrm{H}, \mathrm{H} 5 \mathrm{a}) ; 3.76(\mathrm{t}, \mathrm{J}=6.7,1 \mathrm{H}, \mathrm{H} 2) ; 3.72(\mathrm{dd}, \mathrm{J}=3.1,0.5,1 \mathrm{H}, \mathrm{H} 4) ; 3.66(\mathrm{dd}, \mathrm{J}=$ 10.6, 0.6, 1H, H5b); 3.64 (d, J = 3.2, 1H, H3); 1.75-1.6 (m, 2H, H1'); 1.5-1.2 (m, 24H, H2'-H13'); 0.95-0.8 (m, 3H, H14'). ${ }^{13} \mathrm{C}_{-} \mathrm{NMR}^{\prime}$ (CDCl, 75 MHz) $\delta$ (ppm): 77.8 (C2); 67.6 (C5); 57.6 (C3); 56.0 (C4); 32.1, 31.1, 30.3, 29.8, 29.7, 29.5, 26.3, 22.8 (C1'-C13'); 14.3 (C14'). HRMS m/z: calcd for $\mathrm{C}_{18} \mathrm{H}_{35} \mathrm{O}_{2}[\mathrm{M}+\mathrm{H}]^{+}: 283.2637$; found: 283.2624 . $[\alpha]_{\mathrm{D}}^{25}=+17.6$ (c 1.48, $\left.\mathrm{CHCl}_{3}\right)$.

(18) (a) Lee, T.; Lee, S.; Kwak, Y. S.; Kim, D.; Kim, S. Org. Lett. 2007, 9, 429. (b) Prasad, K. R.; Chandrakumar, A. J. Org. Chem. 2007, 72, 6312. (c) Vichare, P.; Chattopadhyay, A. Tetrahedron: Asymmetry 2010, 21, 1983.

(19) All analyses were in agreement with the data reported in the literature. ${ }^{3 \mathrm{f}}[\alpha]_{\mathrm{D}} 25=+18.1$ (c 0.80 , EtOH). Litt. ${ }^{3 f}[\alpha]_{\mathrm{D}}{ }^{25}=+18.8(\mathrm{c} 0.85$, EtOH). (20) Passiniemi, M.; Koskinen, A. M. P. Org. Biomol. Chem. 2011, 9, 1774.

(21) All analyses were in agreement with the data reported in the literature. ${ }^{3 \mathrm{~h}}[\alpha]_{\mathrm{D}}^{25}=-7.1$ (c $\left.0.46, \mathrm{MeOH}\right)$. Litt. ${ }^{3 \mathrm{~h}}[\alpha]_{\mathrm{D}}^{25}=-7.3(\mathrm{c} 0.46, \mathrm{MeOH})$. 